\title{
CORRIGENDUM
}

\section{RADIOCARBON DATING OF A SPELEOTHEM RECORD OF PALEOCLIMATE FOR ANGKOR, CAMBODIA - CORRIGENDUM}

Quan Hua • Duncan Cook • Jens Fohlmeister • Dan Penny • Paul Bishop • Solomon Buckman

https://doi.org/10.1017/RDC.2017.115, Published by Cambridge University Press, 14 December 2017.

In the original publication of "Radiocarbon Dating of a Speleothem Record of Paleoclimate for Angkor, Cambodia" (Hua et al. 2017) the acknowledgments section omitted the following sentence:

Our special thanks go to the Ministry of Culture and Fine Arts (Cambodia) for permission to undertake this research.

The authors regret this error.

\section{REFERENCE}

Hua Q, Cook D, Fohlmeister J, Penny D, Bishop P, Buckman S. 2017. Radiocarbon Dating of a Speleothem Record of Paleoclimate for Angkor, Cambodia. Radiocarbon 59(6):1873-90. doi: 10.1017/RDC.2017.115 